
Intention of Sports Drinks and Carbonated Drinks. Consumer Behavior Review, 6(1), e-250715.

ISSN: 2526-7884

Editor: Prof. Dr. Marconi Freitas da Costa

E-mail: cbr@ufpe.br
Evaluation: Double blind review

Received: June 05, 2021

Approved: September 26, 2021

\title{
FACTORS INFLUENCING PURCHASE INTENTION OF SPORTS DRINKS AND CARBONATED DRINKS
}

Fatores que influenciam a intenção de compra de bebidas esportivas e gaseificadas

\author{
Ahnaf Chowdhury Niloy ${ }^{1}$ \\ ORCID: http://orcid.org/0000-0002-1103-1385 \\ E-mail: ahnafniloy@outlook.com
}

${ }^{1}$ East West University, Department of Business Administration, Dhaka, Bangladesh

\begin{abstract}
Purpose: This study tries to identify the factors that impact a Bangladeshi carbonated drinks and sports drinks consumer if endorsers are used for brand promotion.

Design/Methodology/Approach:

Quantitative methodology has been adopted for the study. Survey of 460 participants from the target group provided information through a questionnaire designed in Likert scale method, based on the factors - purchase intention, source attractiveness, source credibility, source familiarity and source compatibility. Data has been analyzed through multiple statistical methods including correlation and regression analysis.

Findings: The result of the study revealed purchase intention of carbonated drinks and soft drinks consumers of Bangladesh has a significant positive relationship with
\end{abstract}

\begin{abstract}
Resumo
Objetivo: Este estudo tenta identificar os fatores que impactam um consumidor de bebidas gaseificadas e esportivas de Bangladesh se endossantes são usados para a promoção da marca.

Desenho/Metodologia/Abordagem: A metodologia quantitativa foi adotada para o estudo. A pesquisa com 460 participantes do grupo-alvo forneceu informações por meio de um questionário elaborado na escala do tipo Likert, com base nos fatores - intenção de compra, atratividade da fonte, credibilidade da fonte, familiaridade da fonte e compatibilidade da fonte. Os dados foram analisados por meio de vários métodos estatísticos, incluindo correlação e análise de regressão.

Resultados: 0 resultado do estudo revelou que a intenção de compra dos consumidores
\end{abstract}


attractiveness, credibility, and familiarity of the endorser, but insignificant relationship with source compatibility.

Originality/Value: Study on influencer's impact in carbonated drinks of Bangladesh has limited studies while on sports drinks of Bangladesh is yet not present. Many of the available studies are provided in a holistic approach, while this study is focused on the specific area of influencer endorsement. Such understanding strengthens and broadens the existing knowledge about consumer behavior especially in the carbonated and sports drinks market.

Keywords: Bangladesh, Beverage Market, Consumer Behavior, Influencer Endorsement, Purchase Intention. de bebidas esportivas e gaseificadas de Bangladesh tem uma relação positiva significativa com atratividade, credibilidade e familiaridade do endossante, mas relação insignificante com a compatibilidade da fonte. Originalidade/Valor: 0 estudo sobre 0 impacto do influenciador em bebidas gaseificadas de Bangladesh tem estudos limitados, enquanto sobre bebidas esportivas de Bangladesh ainda não está presente. Muitos dos estudos disponíveis são fornecidos em uma abordagem holística, enquanto este estudo se concentra na área específica de endosso do influenciador. Tal entendimento fortalece e amplia o conhecimento existente sobre o comportamento do consumidor, principalmente no mercado de bebidas gaseificadas e esportivas.

Palavras-chave: Bangladesh, Mercado de Bebidas, Comportamento do Consumidor, Endosso de Influenciador, Intenção de Compra.

This work is licensed under a Creative Commons Attribution 4.0 International License: https://creativecommons.org/licenses/by/4.0/

\section{INTRODUCTION}

With a large population, Bangladesh has been a promising land for business of several global and domestic beverage brands. Although, global giants like Coca-cola and PepsiCo is present with carbonated beverages since the 70's, domestic brands like Akij beverages, Partex Beverages, PRAN Group etc has also been successful in the market with their offerings of carbonated drinks. The concept of sports drinks in Bangladeshi market is comparatively a very new concept as the first sports drink in Bangladesh was introduced by NAAFCO pharma in 2017 (NAAFCO group, 2021). By 2018, though PepsoCo introduced Gatorade, a popular electrolyte sports drink internationally, in the Bangladeshi market a much competitive electrolyte sports drink SMC Plus by Social Marketing Company (SMC) was introduced in 2021 (The Daily Star, 2021).

Use of influencer is the approach of using famous personalities in advertisements for creating promotion of the brand (McCracken, 1986). Carbonated drinks brands in Bangladesh has been practicing the use of influencers for a long time but the use of influencer by sports drinks in Bangladesh was not seen until SMC made Tamim Iqbal, a very popular cricket player of Bangladesh, their brand ambassador (Dhaka Tribune, 2021). Endorsers application in brand promotion increases visibility of the brand in the market (Shrestha, 2019). Purchase intention refers to the probability or intention of buying a product (Burton et al., 1998). Purchase intention is correlated with word of mouth (Shrestha, 2019). If the endorser has an inspiring image and popularity, the consumer's purchase intention is affected by it as well (Staff, 2011).

In the era of internet, social media endorsers also play a vital role as influencers through buzzmarketing and have also proven to be a cheaper option for companies as well (Harrison, 2017; Patel, 2016; Talaverna, 2015). The use of endorsers are considered as a credible, trustworthy and knowledgeable to the generation $\mathrm{z}$ consumers (Lim et al., 2017). The research tries to identify the impact of endorsers in generating purchase intention of sports drinks and carbonated drinks in Bangladesh. Purchase intention is considered as a useful element in forecasting market share and estimated sales for a brand (Morwitz, 2014). This study tries to identify the correlational impact of purchase intention with respect to four variables - source credibility, source attractiveness, source 
compatibility, and source familiarity. Understanding the impacts of these variables can give effective understandings of consumer behavior that can benefit marketing practitioners of carbonated drinks and sports drinks brands for developing promotional strategies for creating a positive approach in Bangladesh.

\section{LITERATURE REVIEW AND HYPOTHESIS DEVELOPMENT}

A consumer's buying behavior is widely connected to celebrity endorsement (Arai et al., 2014). A number of studies suggest that consumer's purchase intention is correlated to influencer or endorser involvement (Goldsmith et al., 2000; Mathur et al., 1997). Purchase intention also indicates the frequency and probability that an individual will buy an item (Phelps \& Hoy, 1996).

\section{Source Credibility}

Credibility refers to the degree to which the source is perceived as having critical information or enough experience to offer a fair-minded judgment (Carroll, 2009; O'Mahony \& Meenaghan, 1997). Ohanian (1990) argued that source credibility and source attractiveness are effective persuasion indicators and adds that attractiveness of source is firmly identified with endorser's appearance that could improve influence dependent on amiability, likeness, or attractive quality to target crowd. Research on advertisements identifies that endorser's physical attractiveness has effect on customer's judgement towards the product (Ohanian, 1990). Messages shared by a credible source can effect customer's trust, decisions, attitudes and behaviors (Wang et al., 2017). An endorser who is seen as profoundly dependable and ability, would prompt shoppers' lack of interest towards the promoting message, bringing about higher acknowledgment of the conveyed message (Metzger et al., 2003). A learned endorser is more powerful at convincing the customer to purchase the item (Bardia et al., 2011). So the hypothesis statements are as follows:

a1. Purchase intention has a significant relationship with source credibility

b1. Purchase intention does not have a significant relationship with source credibility

\section{Source Attractiveness}

A positive correlation has been identified between source attractiveness and purchase intention in a number of earlier studies (Erdogan, 1999; Petty et al., 1983). Effectiveness of a customer is directly correlated with source attractiveness (McGuire, 1985). Endorsers with appealing highlights can apply an uplifting disposition on shoppers accordingly with a buying expectation (Till \& Busler, 2000). Perception towards a brand can be altogether improved by the endorser's allure (Bardia et al., 2011; Hakimi et al., 2011; Tantiseneepong et al., 2012). So the hypothesis statements are as follows:

a2. Purchase intention has a significant relationship with source attractiveness

b2. Purchase intention does not have a significant relationship with source attractiveness

\section{Source Compatibility}

It is obvious that the product and the endorser, if has compatibility, there may have high chances of getting a positive result. An appropriate compatibility between the brand and the influencer gives a success in marketing strategy (Till \& Busler, 1998). Positive attitude towards the influencer's brand can occur if the compatibility between the brand and the endorser exists (Kamins \& Gupta, 1994). A coordinate between an endorser and the brand is the most major objective in accomplishing shoppers' purchase intention (Shimp, 2000). So the hypothesis statements are as follows:

a3. Purchase intention has a significant relationship with source compatibility

b3. Purchase intention does not have a significant relationship with source compatibility 


\section{Source Familiarity}

An individual whose name influences public attention, interest and individual value from the general people is known as a celebrity (Kotler, 2009). Familiarity implies the sensation of similitude by methods for feelings and contact (Erdogan, 1999). If customer finds little dissimilarities with the endorser, also known as mere exposure effect, the impact of purchase intention is likely to be positive (Zajonc, 1968). So the hypothesis statements are as follows-

a4. Purchase intention has a significant relationship with source compatibility

b4. Purchase intention does not have a significant relationship with source compatibility

\section{Hypothesis Set Formulation}

A hypothesis is an assumption or a set of assumptions that are scientifically and logically analyzed based upon established theories to determine the correct assumption or set of assumptions of the overall analysis (Price et al., 2017). In order to drive a conclusion it is essential to analyze all possible options regarding the analysis to justify the correct result. The set of options can be pointed out as the set of assumptions as logically it cannot be assumed that one single or a couple of options to be accurate in a neutral case before analysis. In neutral situation, each option has an equal probability of being the result (Siegmund, 2020).

As Siegmund (2020) notes, in case of calculating the number of probabilities in a sample space of a neutral situation, the formula is derived as $\alpha^{n}$. Here, $\alpha$ stands for the number of possible outcomes and $n$ stands for the number of trials.

Number of elements in the set of hypothesis $=\alpha^{n}$

$\alpha=$ number of possible outcomes

$n=$ number of trials

From the discussion above, the elements found to develop a hypothesis are source credibility, source attractiveness, product match-up and source familiarity with respect to purchase intention. As it can be examined, for each element (ex: source credibility with purchase intention etc.), if there is a relationship there can only be two possible outcomes-

Purchase Intention has a significant relationship with Variable $\mathrm{X}$

Purchase Intention does not have a significant relationship with Variable X

Here, "Variable X" can be referred to source credibility, source attractiveness, source compatibility and source familiarity.

As mentioned earlier from the theory of probability, by calculating using the formula $\alpha$, the number of possible outcomes can be calculated for a neutral situation. In each case, the study tries to identify a correlation between purchase intention and either of the elements - source credibility, source attractiveness, source compatibility and source familiarity. Thus, the number of comparing elements or trials are 4 . As each element or trial provides 2 possible outcomes $(a$ and $b)$, it is determined that value of $\alpha=2$ and value of $n=4$.

So, number of possible outcomes $\quad \begin{aligned} & =\alpha^{\mathrm{n}} \\ & =2^{4} \\ & =16\end{aligned}$

The result signifies that there can have 16 possible set of outcomes if a correlation is to be determined between purchase intention with respect to source credibility, source attractiveness, product match up and source familiarity. The 16 outcomes or elements in the set of hypothesis gives the idea that there may have significant correlation between purchase intention and all the variables, 
no significant correlation between purchase intention and all the variables, or significant relationship between purchase intention and some of the variables may be present.

As it is determined that there can have 16 outcomes, below is calculated the set of hypothesis, signified as $\mathrm{S}_{\mathrm{h}}$.

$\mathrm{S}_{\mathrm{h}}=\mathrm{a} 1 \mathrm{a} 2 \mathrm{a} 3 \mathrm{a} 4, \mathrm{a} 1 \mathrm{a} 2 \mathrm{a} 3 \mathrm{~b} 1, \mathrm{a} 1 \mathrm{a} 2 \mathrm{~b} 3 \mathrm{a} 4, \mathrm{a} 1 \mathrm{a} 2 \mathrm{~b} 3 \mathrm{~b} 4, \mathrm{a} 1 \mathrm{~b} 2 \mathrm{a} 3 \mathrm{a} 4, \mathrm{a} 1 \mathrm{~b} 2 \mathrm{a} 3 \mathrm{~b} 4, \mathrm{a} 1 \mathrm{~b} 2 \mathrm{~b} 3 \mathrm{a} 4, \mathrm{a} 1 \mathrm{~b} 2 \mathrm{~b} 3 \mathrm{~b} 4, \mathrm{~b} 1 \mathrm{a} 2 \mathrm{a} 3 \mathrm{a} 4$, b1a2a3b4, b1a2b3a4, b1a2b3b4, b1b2a3a4, b1b2a3b4, b1b2b3a4, b1b2b3b4

For this study, in each of the subset (ex: a1a2a3b4, a1b2a3b4 etc.) the subset has 4 elements or individual outcomes correlated with purchase intention (\#\#\#\#) of which the 1st element is considered as source credibility, 2nd element is source attractiveness, 3rd is source compatibility and 4 th is source familiarity.

The probability tree model showed in Figure.1 gives a graphical idea of the hypothesis development. The 16 probable outcomes are provided in details in Table 1.

Table 1

Set of Possible Outcomes

\begin{tabular}{|c|c|}
\hline Subset & Outcome \\
\hline$a 1 a 2 a 3 a 4$ & Purchase intention has significant relationship with all the variables \\
\hline$a 1 a 2 a 3 b 1$ & $\begin{array}{l}\text { Purchase intention has significant relationship with source credibility, source } \\
\text { attractiveness and source compatibility but has insignificant relationship with } \\
\text { source familiarity }\end{array}$ \\
\hline$a 1 a 2 b 3 a 4$ & $\begin{array}{l}\text { Purchase intention has significant relationship with source credibility, source } \\
\text { attractiveness and source familiarity but has insignificant relationship with } \\
\text { source compatibility }\end{array}$ \\
\hline$a 1 a 2 b 3 b 4$ & $\begin{array}{l}\text { Purchase intention has significant relationship with source credibility and source } \\
\text { attractiveness but has insignificant relationship with source compatibility and } \\
\text { source familiarity }\end{array}$ \\
\hline$a 1 b 2 a 3 a 4$ & $\begin{array}{l}\text { Purchase intention has significant relationship with source credibility, source } \\
\text { compatibility and source familiarity but has insignificant relationship with source } \\
\text { attractiveness }\end{array}$ \\
\hline$a 1 b 2 a 3 b 4$ & $\begin{array}{l}\text { Purchase intention has significant relationship with source credibility and source } \\
\text { compatibility but has insignificant relationship with source attractiveness and } \\
\text { source familiarity }\end{array}$ \\
\hline$a 1 b 2 b 3 a 4$ & $\begin{array}{l}\text { Purchase intention has significant relationship with source credibility and source } \\
\text { familiarity but has insignificant relationship with source attractiveness and } \\
\text { source compatibility }\end{array}$ \\
\hline$a 1 b 2 b 3 b 4$ & $\begin{array}{l}\text { Purchase intention has significant relationship with source credibility but has } \\
\text { insignificant relationship with source attractiveness, source compatibility and } \\
\text { source familiarity }\end{array}$ \\
\hline$b 1 a 2 a 3 a 4$ & $\begin{array}{l}\text { Purchase intention has significant relationship with source attractiveness, source } \\
\text { compatibility and source familiarity but has insignificant relationship with source } \\
\text { credibility }\end{array}$ \\
\hline$b 1 a 2 a 3 b 4$ & $\begin{array}{l}\text { Purchase intention has significant relationship with source attractiveness and } \\
\text { source compatibility but has insignificant relationship with source credibility and } \\
\text { source familiarity }\end{array}$ \\
\hline$b 1 a 2 b 3 a 4$ & $\begin{array}{l}\text { Purchase intention has significant relationship with source attractiveness and } \\
\text { source familiarity but has insignificant relationship with source credibility and } \\
\text { source compatibility }\end{array}$ \\
\hline$b 1 a 2 b 3 b 4$ & $\begin{array}{l}\text { Purchase intention has significant relationship with source attractiveness but has } \\
\text { insignificant relationship with source credibility, source compatibility and source } \\
\text { familiarity }\end{array}$ \\
\hline$b 1 b 2 a 3 a 4$ & $\begin{array}{l}\text { Purchase intention has significant relationship with source compatibility and } \\
\text { source familiarity but has insignificant relationship with source credibility and } \\
\text { source attractiveness }\end{array}$ \\
\hline$b 1 b 2 a 3 b 4$ & Purchase intention has significant relationship with source compatibility but has \\
\hline
\end{tabular}

$b 1 b 2 a 3 b 4$ 
insignificant relationship with source credibility, source attractiveness and source familiarity

b1b2b3a4 Purchase intention has significant relationship with source familiarity but has insignificant relationship with source credibility, source attractiveness and source compatibility

b1b2b3b4 Purchase intention has no significant relationship with any variables

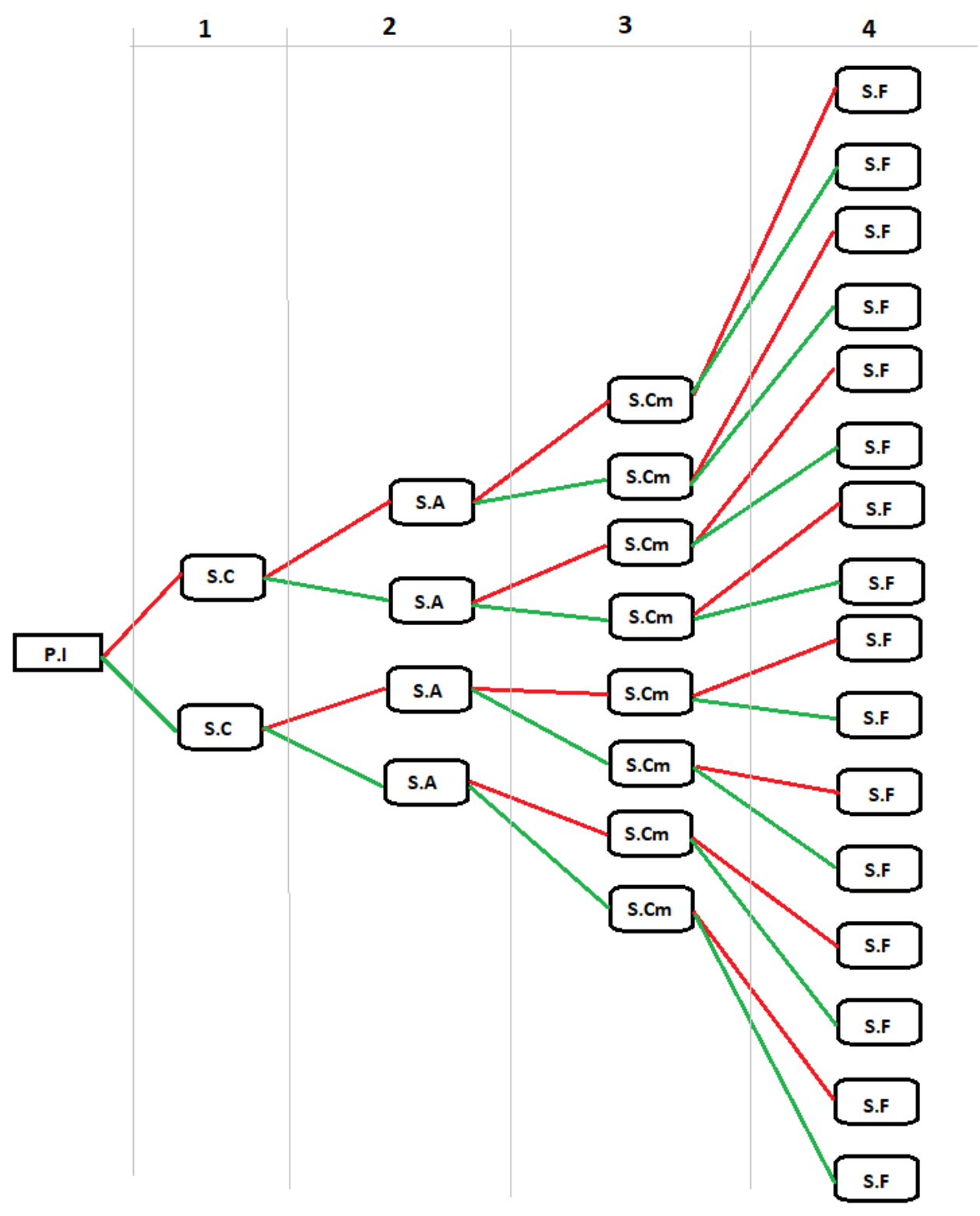

b

Figure.1 Probability tree model of hypothesis development

Note: $\mathbf{P . I}=$ Purchase Intention, $\mathbf{S} . \mathbf{C}=$ Source Credibility, $\mathbf{S . A}=$ Source Attractiveness, $\mathbf{S} . \mathbf{C m}=$ Source Compatibility, $\mathbf{S . F}=$ Source Familiarity, $\mathbf{a}=$ has significant relationship, $\mathbf{b}=$ does not have significant relationship. 


\section{METHODOLOGY}

The research contains both primary and secondary data from several sources. The primary data was collected via a survey through google forms. Secondary data includes several published journal articles, books, news, blogs etc. In order to showcase market growth and consumption pattern, data collected from Marketline Research Database has also been shown graphically. The sample for the research was people who reside in urban areas of Dhaka and Chittagong and purchases branded products one or multiple times over a year. Judgmental sampling has been followed in conducting the survey and the participants have been chosen based on the fact that if they had purchased any product that is endorsed by a brand ambassador or influencer in the past 6 months. Survey was conducted in Dhaka and Chittagong only. Around 460 participants participated in the survey. It is considered that samples containing more than 200 respondents are large samples (Kline, 1998) and considered to provide valid or meaningful results of the experiment (Eldred, 1987). As the study contains 460 respondents, the dataset is both large and sufficient to provide a valid result.

The respondents participated in through a survey questionnaire based on Likert-scales. The questionnaire was divided into two parts where the first part was related to demographic information and the second part contained questions regarding source credibility, source attractiveness, source compatibility, source familiarity and purchase intention. The scale was anchored on " 5 - Strongly Agree" to "1 - Strongly Disagree". Constructs present in the research instruments were source credibility, source attractiveness, source compatibility and source familiarity as independent variables while purchase intention was considered as dependent variable. The demographic determinants were sex, age, marital status, profession, educational background and monthly household income. Statistical Package for Social Sciences (SPSS) was used for the calculation of the analysis.

\section{ANALYSIS AND FINDINGS \\ Demographic Analysis}

The demographic information collected through the survey gives the information that $58.3 \%$ respondents were male and $41.7 \%$ were female. The largest group of respondents are aged 18-24 years. About $90.9 \%$ of the respondents were unmarried and about $87.2 \%$ respondents are students and $68.9 \%$ are in bachelors or honors program. $42 \%$ of the respondents have a monthly family income of below 30,000 BDT.

Table 2

Demographic Profile of Respondents

\begin{tabular}{lcc}
\hline Sex & Frequency & Percentage \\
Male & 268 & $58.3 \%$ \\
Female & 192 & $41.7 \%$ \\
Age of Respondents & & \\
$18-24$ years old & 386 & $83.9 \%$ \\
$25-29$ years old & 47 & $10.2 \%$ \\
$30-39$ years old & 20 & $4.3 \%$ \\
40 years and above & 2 & $.4 \%$ \\
Below 18 years old & 5 & $1.1 \%$ \\
Marital Status & & \\
Divorced/Separated & 1 & $.2 \%$ \\
Married & 41 & $8.9 \%$ \\
Unmarried & 418 & $90.9 \%$ \\
Educational Background & & \\
English medium & & $.2 \%$ \\
Honors/Bachelors & 1 & $68.9 \%$ \\
HSC & 317 & $23.9 \%$
\end{tabular}




\begin{tabular}{lcc} 
Masters & 27 & $5.9 \%$ \\
SSC & 4 & $.9 \%$ \\
Undergraduate & 1 & $.2 \%$ \\
& & \\
Profession & 1 & \\
D \& A & 18 & $.2 \%$ \\
Executive/Manager & 1 & $3.9 \%$ \\
Government Service & 1 & $.2 \%$ \\
Job Holder & 16 & $.2 \%$ \\
Professional & 21 & $3.5 \%$ \\
Self Employed/Own Business & 401 & $4.6 \%$ \\
Student & 1 & $87.2 \%$ \\
Student + Part Time Creative Artist & & $.2 \%$ \\
& & \\
Monthly Household Income & 40 & $8.7 \%$ \\
Above BDT 1,00,000 & 111 & $24.1 \%$ \\
BDT 30,000 - BDT 50,000 & 80 & $17.4 \%$ \\
BDT 50,000 - BDT 80,000 & 36 & $7.8 \%$ \\
BDT 80,000 - BDT 1,00,000 & 193 & $42.0 \%$ \\
Below BDT 30,000 & & \\
\hline
\end{tabular}

\section{Reliability Analysis}

Cronbach's coefficient alpha has been used to measure the internal consistency of the scales for conducting the reliability analysis. A reliable threshold value of Cronbach's alpha has to be above 0.7 (Hair et al., 2010). As shown in Table 3. For all the values the Cronbach's alpha is above 0.7 indicating that the survey instrument is reliable for measuring all the variables consistently.

Table 3

Reliability Statistics

\begin{tabular}{lcc}
\hline Variable & Number of Items & Cronbach's Alpha \\
\hline Source Credibility & 6 & 0.800 \\
Source Attractiveness & 5 & 0.794 \\
Source Compatibility & 4 & 0.821 \\
Source Familiarity & 3 & 0.791 \\
Purchase Intention & 6 & 0.844 \\
\hline
\end{tabular}

\section{Correlation Analysis}

A correlation analysis has been conducted to understand the correlations between each variables. The target of the study was to determine correlation among source credibility, source attractiveness, source compatibility and source familiarity with respect to purchase intention. As each of the variables contained more than one questions to determine the respondents reaction, for each variable an average score of multi items were calculated. All the values were found to be significant. The highest correlation value has been identified between Purchase Intention and Source Familiarity $(r=.615, p<0.05)$ followed by Purchase Intention and Source Attractiveness $(r=.555, p<0.05)$. But, though there was a significant positive correlation between Purchase intention and Source compatibility, the value was quite low $(r=.224, p<0.05)$ compared to other variables. This signifies that consumers have a greater impact in having a purchase intention of carbonated drinks and sports drinks, if the endorser is familiar and attractive. A normal distribution or bell shaped curve is present as the skewness for all the variables were below \pm 2.0 and all variables' kurtosis was less than the cutoff value of \pm 10 . 
Table 4

Correlation Analysis

\begin{tabular}{llllll}
\hline Variables & PI & SC & SA & SCm & SF \\
\hline Purchase Intention (PI) & 1 & & & & \\
Source Credibility (SC) & $.517^{*}$ & 1 & & & \\
Source Attractiveness (SA) & $.555^{*}$ & $.386^{*}$ & 1 & & \\
Source Compatibility (SCm) & $.224^{*}$ & $.438^{*}$ & $.115^{* *}$ & 1 & \\
Source Familiarity (SF) & $.615^{*}$ & $.597^{*}$ & $.478^{*}$ & $.300^{*}$ & 1 \\
& & & & & \\
Mean & 2.96 & 3.59 & 2.79 & 3.76 & 3.31 \\
Standard Deviation & .794 & .776 & .834 & .798 & 0.39 \\
Skewness & -.260 & -.794 & -.013 & -.587 & -.587 \\
Kurtosis & -.079 & .418 & -.255 & .529 & .270 \\
\hline
\end{tabular}

Note: *Correlation is significant at 0.01 level (two-tailed)

** Correlation is significant at 0.05 level (two-tailed)

\section{Linear Regression Analysis and Equation Formulation}

From Table 4 it is clear that there is a significant correlation between purchase intention and the other variables. But, only correlation does not give a clear idea about how much the variables impact in creating purchase intention. For further analysis, a multivariate linear regression was used to assess the relationship between purchase intention and rest of the variables.

Taking purchase intention as the dependent variable and source credibility, source attractiveness, source compatibility and source familiarity as independent variable, the regression model shows that, the $R^{2}=0.488$ which means that the dependent variable is explained around $48.8 \%$ by the variations in the independent variables. The number of observations for the study is 460 .

We can formulate the linear regression equation as follows:

Purchase Intention $(Y)=0.352+0.188 \times$ Source Credibility $\left(\beta_{1}\right)+0.3 \times$ Source Attractiveness $\left(\beta_{2}\right)+$ $0.331 \times$ Source Familiarity $\left(\beta_{3}\right)+0.001 \times$ Source Compatibility $\left(\beta_{4}\right)$; Where, $1 \leq x_{1}, x_{2}, x_{3} \leq 5$

We can say that the hypothesis for the global test is:

Null Hypothesis, $\mathrm{H}_{0}: \beta_{1}=\beta_{2}=\beta_{3}=\beta_{4}=0$

Alternate Hypothesis, $\mathrm{H}_{1}$ : Not all $\beta$ i's are 0

From Table 5 we see that $p<0.01$ thus, $\mathrm{H}_{\mathrm{o}}$ is rejected at $1 \%$ level of significance. Thus, we can conclude that at least one independent variable has the ability to explain the dependent variable. The model is significant at $1 \%$ level of significance.

Table 5

Model Summary, ANOVA, and Coefficients

\begin{tabular}{llllllllll} 
Model & $\mathbf{R}$ & $\begin{array}{c}\text { R } \\
\text { square }\end{array}$ & $\begin{array}{c}\text { Adjusted } \\
\text { R square }\end{array}$ & $\begin{array}{c}\text { Std. Error of } \\
\text { the estimate }\end{array}$ & $\begin{array}{c}\text { R } \\
\text { square } \\
\text { change }\end{array}$ & F change & df1 & df2 & $\begin{array}{c}\text { Sig. F } \\
\text { change }\end{array}$ \\
\hline 1 & 0.699 & 0.488 & 0.483 & 0.57040 & 0.488 & 108.416 & 4 & 455 & 0.000 \\
\hline
\end{tabular}

\begin{tabular}{cccccc}
\hline Model & Sum of & Df & Mean Square & F & Sig \\
\hline Squares & 141.099 & 4 & 35.275 & 108.416 & 0.000 \\
Regression & 148.041 & 455 & 0.325 & & \\
Total & 289.140 & 459 & & & \\
\hline
\end{tabular}

\begin{tabular}{ccccccc} 
Model & $\begin{array}{c}\text { Unstandardized } \\
\text { Beta }\end{array}$ & $\begin{array}{c}\text { Standardized } \\
\text { Beta }\end{array}$ & $\mathrm{T}$ & Sig. & $\begin{array}{c}95 \% \\
\text { confidence } \\
\text { (lower bound) }\end{array}$ & $\begin{array}{c}95 \% \\
\text { confidence } \\
\text { (higher bound) }\end{array}$ \\
\hline Constant & 0.352 & & 2.218 & 0.027 & 0.040 & 0.663 \\
\hline
\end{tabular}




\begin{tabular}{ccccccc}
\hline SC & 0.188 & 0.182 & 4.042 & 0.000 & 0.097 & 0.280 \\
SA & 0.300 & 0.315 & 8.130 & 0.000 & 0.227 & 0.372 \\
SF & 0.331 & 0.356 & 7.993 & 0.000 & 0.250 & 0.413 \\
SCm & 0.001 & 0.001 & 0.021 & 0.989 & -0.073 & 0.074 \\
\hline
\end{tabular}

Note: $\mathbf{S} . \mathbf{C}=$ Source Credibility, S.A = Source Attractiveness, $\mathbf{S . C m}=$ Source Compatibility, $\mathbf{S} . \mathbf{F}=$ Source Familiarity

For the individual variables, we can formulate the following tests to determine the impact.

\section{For Source Credibility}

$\mathrm{H}_{0}: \beta_{1}=0$

$\mathrm{H}_{1}: \beta_{1} \neq 0$

As $p<0.01$, thus $\mathrm{H}_{0}$ is rejected at $1 \%$ level of significance. Thus, source credibility has significant impact on purchase intention. If source credibility increases by one-unit purchase intention will increase by 0.188 units.

\section{For Source Attractiveness}

$\mathrm{H}_{0}: \beta_{2}=0$

$\mathrm{H}_{1}: \beta_{2} \neq 0$

As $p<0.01$, thus $\mathrm{H}_{0}$ is rejected at $1 \%$ level of significance. Thus, source attractiveness has significant impact on purchase intention. If source attractiveness increases by one-unit purchase intention will increase by 0.3 units.

\section{For Source Familiarity}

$\mathrm{H}_{0}: \beta_{3}=0$

$\mathrm{H}_{1}: \beta_{3} \neq 0$

As $p<0.01$, thus $\mathrm{H}_{0}$ is rejected at $1 \%$ level of significance. Thus, source familiarity has significant impact on purchase intention. If source familiarity increases by one-unit purchase intention will increase by 0.331 units.

\section{For Source Compatibility}

\section{$\mathrm{H}_{0}: \beta_{4}=0$}

$\mathrm{H}_{1}: \beta_{4} \neq 0$

As $p>0.1$, thus $\mathrm{H}_{0}$ cannot be rejected at $10 \%$ level of significance. Thus, source compatibility does not have significant impact on purchase intention.

\section{DISCUSSION}

From the study it is clear that the variables chosen to determine purchase intention of carbonated drinks and sports drinks in Bangladesh were all positively correlated with purchase intention of consumers. However, the consumers tend to have a greater purchase intention of carbonated drinks and sports drinks if the endorser is familiar and attractive. Endorsers' credibility also impacts greatly in generating purchase intention but compatibility or product matchup of the endorser is an insignificant element that generates purchase intention of carbonated drinks and sports drinks in Bangladeshi consumers.

The study gives a clear idea of Bangladeshi consumers that in case of purchasing a branded carbonated drinks or sports drinks, the consumer tends to purchase it if the endorser is familiar, credible, and attractive. The result is consistent with the study of Goldsmith et al. (2000) and Tantiseneepong et al. (2012) who showed that a consumers' willingness to purchase the product and subsequently actively seek out the product in a store is dependent upon endorser's positive appeal that reflects a positive brand image. As the variables represent a positive brand image, the purchase intention is also significantly impacted.

The study also highlights the fact that in case of promoting a carbonated drinks and sports drinks in the Bangladeshi market, it is more impactful if the endorser is more familiar, attractive and credible rather compatible. Thus the endorser's familiarity, attractiveness, and credibility will 
generate higher sales for carbonated drinks and sports drinks in Bangladesh. So the study clearly identifies that from the 16 hypothesis developed earlier which are shown in Table 1. and Figure 1., outcome a1a2b3a4 - Purchase intention has significant relationship with source credibility, source attractiveness and source familiarity but has insignificant relationship with source compatibility, is found to be true.

\section{CONCLUSION AND RECOMMENDATION}

This research has highlighted the use of endorsers, both celebrity and social media for generating a significantly positive purchase intention of consumers in case of carbonated drinks and sports drinks in Bangladeshi market. The findings of the study points to the fact that Bangladeshi consumers tend to have a greater purchase intention of carbonated drinks and sports drinks, if in advertisements or promotional campaigns the endorser used is familiar, credible, and attractive. Overall, the study gives a new insight of consumer behavior to the carbonated drinks and sports drinks market of Bangladesh and its use of endorsers, as such study is not present in Bangladeshi context earlier.

The study contributes to the emerging market of carbonated drinks and sports drinks market in Bangladesh that will assist a brand to understand the traits that should be considered in case of choosing endorser when it comes to promoting carbonated drinks and sports drinks in Bangladesh. From Figure 2 it is identifiable that sports drinks and carbonated drinks market is expanding over the years in Bangladesh and in order to be successful in this market, influencer and celebrity endorsement can be a key strategy for gaining greater market share. But for the successful implication of the strategy, the brand must understand the factors that influence the consumers of this region thus the study gives a clear idea for a successful approach when it comes to endorsement selection.

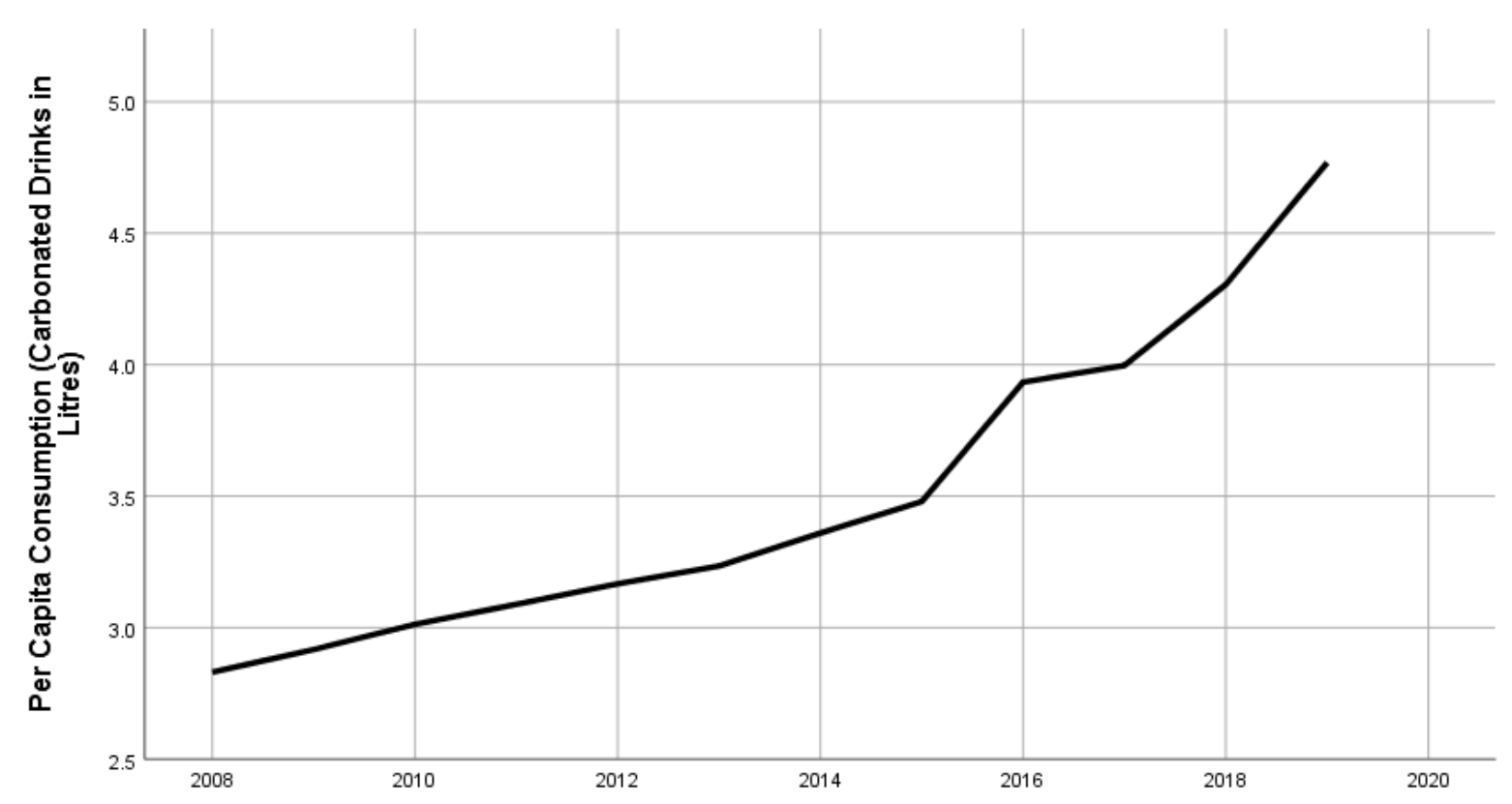

(a) 


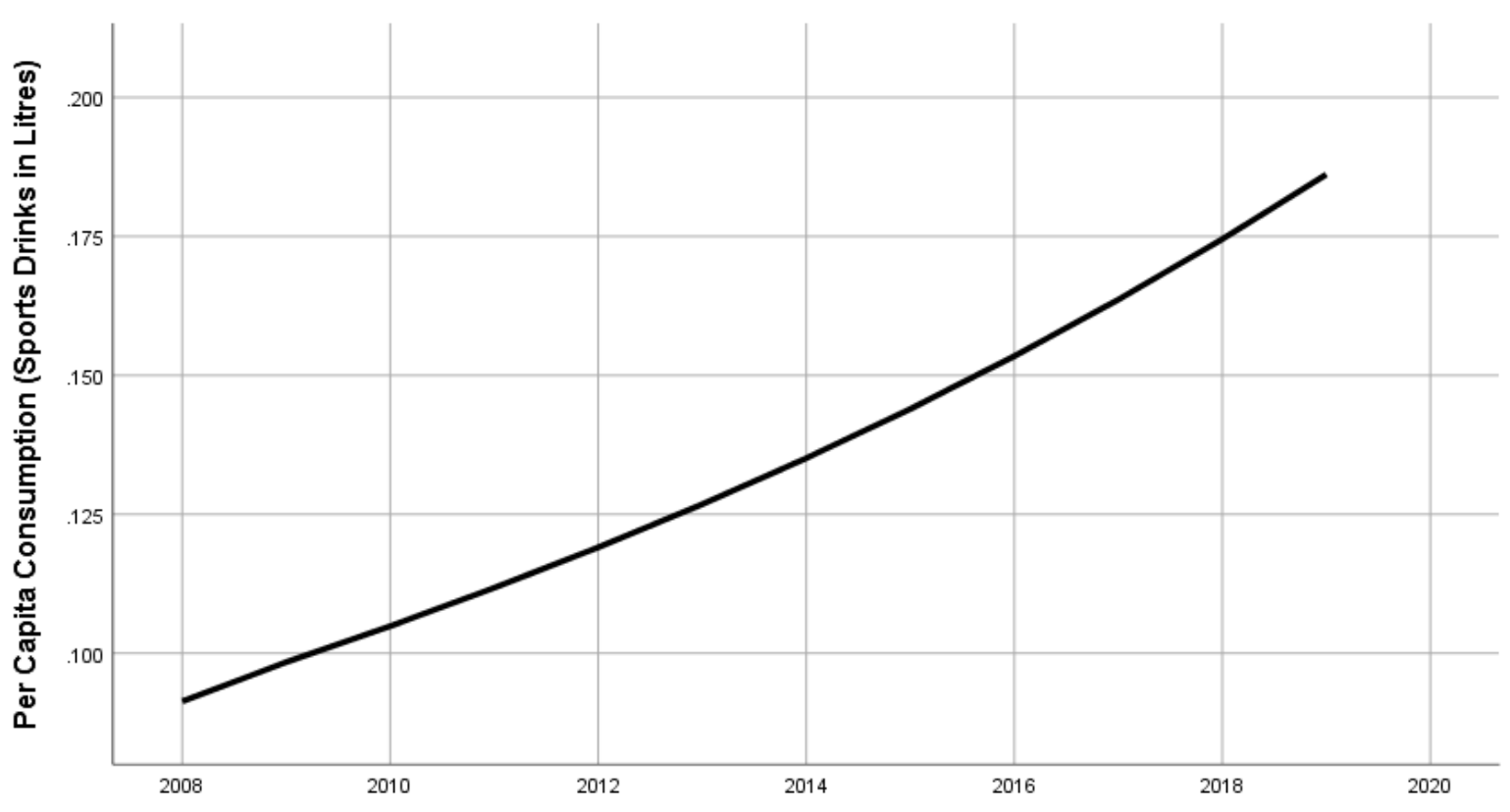

(b)

Figure 2: (a) Per Capita Consumption of Carbonated Drinks (in Litres) in Bangladesh from period 2008-2019, (b) Per Capita Consumption of Sports Drinks (in Litres) in Bangladesh from period 2008-2019

The study recommends that in case of promoting sports drinks and carbonated drinks in Bangladesh through endorsers, brands should put more weight on endorsers' familiarity, attractiveness and credibility compared to compatibility. As found in the study that compatibility or product match-up is insignificant than the other variables, highlighting the product and its features more or finding a product match up with the endorser can be given less importance. Rather, the brand should put more emphasis in understanding the familiarity of the endorser with the target customer, the attractiveness of the endorser to the target customer and the credibility of the endorser to generate a greater impact in creating effective purchase intention.

Brand practitioners could formulate a deeper understanding through by obtaining more information about demographic and psychographic backgrounds of consumers. Larger dataset and seasonality may have impact on the results however the author believes that the results will vary slightly. However, other variables might be worthy of investigating, such as source nationality, prestige, trustworthiness, product pricing etc. The study could also be replicated in other regions and countries and the findings could be used by multinationals for expansion of carbonated drinks or sports drinks in other regions and nations with a successful endorsement strategy.

\section{References}

Arai, A., Ko, Y. J., \& Ross, S. (2014). Branding athletes: Exploration and conceptualization of athlete brand image. Sport Management Review, 17(2), 97-106. doi: 10.1016/j.smr.2013.04.003

Bardia, Y., Abed, A., \& Majid, N. (2011). Investigate the impact of celebrity endorsement on brand image. European Journal of Scientific Research, 58(1), 116-132.

Burton, S., Lichtenstein, D. R., Netemeyer, R. G., \& Garretson, J. A. (1998). A scale for measuring attitude toward private label products and an examination of its psychological and behavioral correlates. Journal of the Academy of Marketing Science, 26(4), 293. https://doi:10.1177/0092070398264003 
Carroll, A. (2009). Brand communications in fashion categories using celebrity endorsement. Journal of Brand Management, 17(2), 146-158. doi:10.1057/bm.2008.42

Dhaka Tribune. (2021). Tamim Iqbal new face of SMC Plus Electrolyte Drink. Retrieved from https://www.dhakatribune.com/business/2021/05/23/tamim-iqbal-new-face-of-smc-pluselectrolyte-drink

Eldred, G. (1987). Real estate: Analysis and strategy. New York: Harper \& Row.

Erdogan, B. Z. (1999). Celebrity Endorsement: A Literature Review. Journal of Marketing Management, 15(4), 291-314. doi:10.1362/026725799784870379

Goldsmith, R. E., Lafferty, B. A., \& Newell, S. J. (2000). The Impact of Corporate Credibility and Celebrity Credibility on Consumer Reaction to Advertisements and Brands. Journal of Advertising, 29(3), 43-54. doi:10.1080/00913367.2000.10673616

Hair, J. F. J., Black, W. C., Babin, B. J., Anderson, R. E., \& Tatham, R. L. (2010). Multivariate Data Analysis: A Global Perspective, . New Jersey: Prentice Hall.

Hakimi, B., Abedniya, A., \& Zaeim, M. (2011). Investigate the impact of celebrity endorsement on brand images. European Journal of Scientific Research, 58(1), 116-132.

Harrison, K. (2017). Top 10 trends that will transform digital marketing in 2017. Retrieved from https://www.forbes.com/sites/kateharrison/2017/01/09/top-10-trendsthat-will-transformdigital-marketing-in-2017/\#7e6d507d3bf5

Kamins, M. A., \& Gupta, K. (1994). Congruence between spokesperson and product type: A matchup hypothesis perspective. Psychology \& Marketing, 11(6), 569-586. doi: 10.1002/mar.4220110605

Kline, R. B. (1998). Principles and practice of structural equation modeling. New York: The Guilford Press.

Kotler, P. (2009). Marketing Management: A South Asian Perspective: Pearson Education.

Lim, X., Radzol, A. R. M., Cheah, J., \& Wong, M. W. (2017). The Impact of Social Media Influencers on Purchase Intention and the Mediation Effect of Customer Attitude.

Mathur, L. K., Mathur, I., \& Rangan, N. (1997). The wealth effects associated with a celebrity endorser: The Michael Jordan phenomenon. Journal of Advertising Research, 37(3), 67-73.

McCracken, G. (1986). Culture and Consumption: A Theoretical Account of the Structure and Movement of the Cultural Meaning of Consumer Goods. Journal of Consumer Research, 13(1), 71-84. doi:10.1086/209048

McGuire, W. J. (1985). Attitudes and Attitude Change. In G. Lindzey \& E. Aronson (Eds.), Handbook of Social Psychology (3rd ed., Vol. 2, pp. 233-346). New York: Random House.

Metzger, M. J., Flanagin, A. J., Eyal, K., Lemus, D. R., \& McCann, R. M. (2003). Credibility for the 21st Century: Integrating Perspectives on Source, Message, and Media Credibility in the Contemporary Media Environment. Annals of the International Communication Association, 27(1), 293-335. doi:10.1080/23808985.2003.11679029

Morwitz, V. (2014). Consumers' Purchase Intentions and their Behavior. Foundations and Trends® in Marketing, 7(3), 181-230. doi:10.1561/1700000036

NAAFCO group. (2021). Timeline. Retrieved from http://naafco.com/timeline/

O'Mahony, S., \& Meenaghan, T. (1997). The impact of celebrity endorsements on consumers. Irish Marketing Review, 10(2), 15-24.

Ohanian, R. (1990). Construction and Validation of a Scale to Measure Celebrity Endorsers' Perceived Expertise, Trustworthiness, and Attractiveness. Journal of Advertising, 19(3), 39-52. doi:10.1080/00913367.1990.10673191

Patel, D. (2016). Top 8 marketing trends that will define 2017. Retrieved from https://www.entrepreneur.com/article/284525

Petty, R. E., Cacioppo, J. T., \& Schumann, D. (1983). Central and Peripheral Routes to Advertising Effectiveness: The Moderating Role of Involvement. Journal of Consumer Research, 10(2), 135146. doi:10.1086/208954

Phelps, J. E., \& Hoy, M. G. (1996). The Aad-Ab-PI relationship in children: The impact of brand familiarity and measurement timing. Psychology \& Marketing, 13(1), 77-105. doi: 10.1002/(SICI)1520-6793(199601)13:1 
Price, P. C., Jhangiani, R., Chiang, I.-C. A., Leighton, D. C., \& Cuttler, C. (2017). Research methods in psychology (3rd American ed.): Southern Arkansas University.

Shimp, T. A. (2000). Advertising, Promotion \& Supplemental Aspects of Integrated Marketing Communications: Dryden Press.

Shrestha, S. (2019). Celebrity Endorsement and Purchase Intention: A Structural Equation Modeling Approach. Management Dynamics, 22(1), 35-46. doi:_10.3126/md.v22i1.30237

Siegmund, D. O. (2020). Probability theory. Retrieved from https://www.britannica.com/science/probability-theory/The-birthday-problem

Staff, F. (2011). Hollywood's most trustworthy celebrities. Retrieved from https://www.forbes.com/2011/02/07/most-trustworthy-celebrities-businessentertainment.html\#7cb9acca1bb5

Talaverna, M. (2015). 10 Reasons Why Influencer Marketing is the Next Big Thing. Retrieved from http://www.adweek.com/digital/10-reasons-why-influencermarketingis-the-next-big-thing/

Tantiseneepong, N., Gorton, M., \& White, J. (2012). Evaluating responses to celebrity endorsements using projective techniques. Qualitative Market Research: An International Journal, 15(1), 5769. doi:10.1108/13522751211191991

The Daily Star. (2021). SMC Introduces SMC Plus Electrolyte Drink. Retrieved from https://www.thedailystar.net/pr/news/smc-introduces-smc-plus-electrolyte-drink-2084737

Till, B. D., \& Busler, M. (1998). Matching products with endorsers: attractiveness versus expertise. Journal of Consumer Marketing, 15(6), 576-586. doi:10.1108/07363769810241445

Till, B. D., \& Busler, M. (2000). The Match-Up Hypothesis: Physical Attractiveness, Expertise, and the Role of Fit on Brand Attitude, Purchase Intent and Brand Beliefs. Journal of Advertising, 29(3), 1-13. doi:10.1080/00913367.2000.10673613

Wang, S. W., Kao, G. H.-Y., \& Ngamsiriudom, W. (2017). Consumers' attitude of endorser credibility, brand and intention with respect to celebrity endorsement of the airline sector. Journal of Air Transport Management, 60, 10-17. doi: 10.1016/j.jairtraman.2016.12.007

Zajonc, R. B. (1968). Attitudinal effects of mere exposure. Journal of Personality and Social Psychology, 9(2, Pt.2), 1-27. doi:10.1037/h0025848 